\title{
Analysis and experimental usage of CFRP wrap type on flexural strength of concrete beam
}

\author{
Johannes Tarigan ${ }^{1, *}$, Andrew Pakpahan ${ }^{1, *}$, Medis Surbakti ${ }^{1}$, Nursyamsi Nursyamsi ${ }^{1}$ \\ ${ }^{1}$ Department of Civil Engineering, Universitas Sumatera Utara, 20155 Medan, Indonesia
}

\begin{abstract}
Today, reinforced concrete structures are commonly used in buildings because the price cheaper than steel structures. However, many concrete structures are damaged. There are several ways to overcome this problem, and one of them is by strengthening the structure using Fiber Reinforced Polymer (FRP). This study discussed the flexural strength of reinforced concrete beams using Fiber Reinforced Polymer (FRP). In this case, the researchers used Carbon Fiber Reinforced Polymer (CFRP) Wrap Type as the external reinforcement. The beam's dimension was $15 \times 25 \mathrm{~cm}$ with a length of $320 \mathrm{~cm}$. Based on the analysis results, the beam using CFRP Wrap type can increase the load $3.12 \%$ times. Furthermore, the experimental results show that the beam with the CFRP type Wrap increases the load by 2.5 times. In conclusion, beams strengthened with CFRP Wrap type can inhibit initial cracks and hold the tensile and flexural strength greater than un-strengthened beams.
\end{abstract}

\section{Introduction}

Nowadays, concrete is being used more frequently in many buildings as a construction technology than steel or wood. Having several advantages, it is not surprising if concrete is being used as the material for building construction. However, many old concrete buildings have been damaged now. Based on an economic standpoint, rebuilding or redesigning old damaged buildings is not feasible. Thus, in this kind of situation, one of the possible ways is that the concrete should be strengthened or repaired. The strengthening process can be applied on concrete buildings to increase its load capacity.

It has been found that there are many ways that can be used to strengthen a structure like column or beam. Several common ways are including putting a casing on the concrete construction or known as "jacketing" using concrete or Fiber Reinforced Polymer (FRP) materials in the column. To strengthen a beam can be install steel plates or FRP under the beam ${ }^{1,2,3}$. In this research will focus on strengthening of beam with FRP material.

There are many kinds of Fiber Reinforced, such as CFRP (Carbon Fiber Reinforced Polymer), GFRP (Glass Fiber Reinforced Polymer), Aramid Fiber, Basalt Fiber. All four materials have similar function with a thin steel plate as the strengthening of the reinforced concrete beams that is to strengthen the tensile part of the reinforced concrete beams.

FRP has a greater tensile strength than steel, and it also has a relatively high stiffness. Furthermore, FRP has a lighter weight than other reinforcement, and it is also resistant to corrosion. As FRP is more practical, the installation process is easier. Despite its relatively expensive price, FRP provides the most economical solution of dealing with reinforcement because it can dramatically reduce labor costs.

The aims of this research were to conduct an experiment on the flexural strength of beam without CFRP wrap and with CFRP wrap. Then the results of this study will be compared with previous research conducted at USU ${ }^{4,5,6}$ using steel plate reinforcement, CFRP type plate and GFRP type wrap.

\section{Literature studies}

\subsection{The previous study results}

Many studies related to structure maintenance using FRP have been done before. Pangestuti and Handayani ${ }^{1}$ discussed the use of CFRP as an external strengthening on reinforced concrete beam structure. The beam's dimension was $150 \times 250 \mathrm{~mm}$ with a length of $2 \mathrm{~m}$ and two treatments. The first beam (control beam) was strengthened using a steel reinforcement while the second beam was not strengthened using a steel reinforcement but coated with CFRP. According to this research, the placement of CFRP on the tensile part of the beam inhibited the initial crack and increased its flexural strength by $50 \%$.

Another study by Ireneus Petrico ${ }^{2}$ compared the flexural strength of a reinforced concrete beam using

\footnotetext{
* Corresponding author: johannes.tarigan@usu.ac.id ${ }^{1}$ andrew.agaton@gmail.com ${ }^{2}$
} 
CFRP and GFRP. The results of the analysis and experiment using CFRP and GFRP showed a significant increase in the flexural strength of the concrete. CFRP increased the flexural strength by $65.934 \%$ whereas GFRP only increased the flexural strength by $43.956 \%$. When comparing both strengthening materials, CFRP was stronger than GFRP in increasing the flexural strength.

Alnadher $\mathrm{Ali}^{3}$ and colleagues on their research investigated reinforced concrete beams with and without CFRP using experimental methods with 16 reinforced concrete cast with SCC (Self Consolidating Concrete) concrete design. The beam's dimension was $240 \mathrm{x} 120 \mathrm{x}$ $1840 \mathrm{~mm}$. The compressive strength used was $44.6 \mathrm{MPa}$, and its tensile strength was $4.27 \mathrm{MPa}$. The tensile strength for $\mathrm{D} 8 \mathrm{~mm}$ was $618 \mathrm{MPa}$ whereas the tensile strength for $\mathrm{D} 10 \mathrm{~mm}$ was $621 \mathrm{MPa}$. The procedure was performed by loading at one point using INSTRON 8806 Universal Testing Machine (UTM) tool with a capacity of $2500 \mathrm{kN}$. The research results showed that there was an increase in the flexural strength of the reinforced concrete beams by $7.4 \%$ if compared with the flexural strength of the reinforced concrete without CFRP.

Manna Haloho and Johannes Tarigan ${ }^{4}$ on their research discussed the strengthening of reinforced concrete beams using anchored steel plate. The beam's dimension was $15 \times 25 \mathrm{~cm}$ with a length of $320 \mathrm{~cm}$. Based on the results, there was an increase in the beam strength by 2.44 times its initial strength. It can be concluded that the application of steel plate on the tensile area can increase its strength and decrease its deflection. On the other hand, the application of an anchor to paste the steel plate with the concrete can resolve the problem of falling plate from the concrete beam.

Another research by Ivandy Yoman and Johannes Tarigan $^{5}$ compared the strength of reinforced concrete beams strengthened using steel plate and Fiber Reinforced Polymer (FRP). The type of Fiber Reinforced Polymer used was the Carbon Fiber Reinforced Polymer (CFRP) Plate type. The dimension of the beam was $15 \times 25 \mathrm{~cm}$ with a length of $320 \mathrm{~cm}$. Based on the analysis results, there was an increase in the beam's strength with FRP by 1.991 times its initial strength, and there was also an increase in the beam strength with the steel plate by 1.64 times its initial strength. The test also showed that the beam's strength with FRP increased by 1.44 times its initial strength while the beam strength with the steel plate increased by 1.056 times its initial strength. Based on the research, it can be concluded that using FRP on the tensile area can withstand more strength than the steel plate and can inhibit initial crack.

J. Tarigan, F. Muhammad and T. Sitorus ${ }^{6}$ also compared the strength of reinforced concrete beams strengthened using Fiber Reinforced Polymer (FRP). The type of FRP used in their research was Glass Fiber Reinforced Polymer Wrap Type (GFRP). The beam's dimension was $15 \times 25 \mathrm{~cm}$ with a length of $320 \mathrm{~cm}$. Based on the analysis results, the beam strength with GFRP increased by 1.877 times its initial strength whereas the beam strength with GFRP increased by 1.333 times its initial strength. Thus, it can be concluded that using GFRP on the tensile area can hold more strength than a common concrete beam and inhibit initial crack.

In Table 1 show mechanical properties of Steel Plate, CFRP Plate type, GFRP Wrap Type and CFRP Wrap Type.

Table 1. Steel Plate and FRP Specifications

\begin{tabular}{|c|c|c|c|}
\hline Products & $\begin{array}{c}\text { Tensile } \\
\text { Strength } \\
\text { (Mpa) }\end{array}$ & $\begin{array}{c}\text { E-modulus } \\
\text { (Mpa) }\end{array}$ & $\begin{array}{c}\text { Thickness } \\
\text { (mm) }\end{array}$ \\
\hline Steel Plate & 333.5 & 200,000 & 5 \\
\hline $\begin{array}{c}\text { CFRP } \\
\text { Plate Type }\end{array}$ & 2800 & 160,000 & 1.2 \\
\hline $\begin{array}{c}\text { GFRP } \\
\text { Wrap Type }\end{array}$ & 2350 & 185,000 & 0.39 \\
\hline $\begin{array}{c}\text { CFRP } \\
\text { Wrap Type }\end{array}$ & 4800 & 234,000 & 0.131 \\
\hline
\end{tabular}

From Table 1 it can be seen that the carbon fiber CFRP wrap type has higher tensile strength and modulus of elasticity compared to Steel Plate, CFRP plate Type and GFRP wrap type.

\subsection{Theory of FRP on Reinforced Concrete Beam}

Fiber Reinforced Polymer (FRP) is a kind of plate/thin sheet which has carbon fiber, glass, aramid, basalt and fiber inside. There are three principles of using FRP in strengthening they are as follows: to increase its moment capacity of flexure, to increase of shear, and to increase axial load on structures.

Specifically, fiber materials which are applied to strengthen and repair the reinforced concrete can be glass fiber, carbon, aramid and basalt. Each of them has a similarity between one and another. The selection of the fiber type for strengthening or repairing certain structure depends on some factors, such as the structure type, available budget, planned load, environmental condition, and others.

In this paper will be focus to strengthening of concrete beam using CFRP wrap type. Therefor in this section will be discuss theory of stress strain in concrete beam without CFRP and with CFRP. The reference can be found at ACI $440^{8}$.

A stress-strain condition of the concrete cross section which is flexed can be seen in Figure 1.

$\mathrm{Cc}$ is concrete compressive force of the concrete, Ts is steel reinforcement tensile strength and $J d$ is distance from $\mathrm{Cc}$ to Ts.

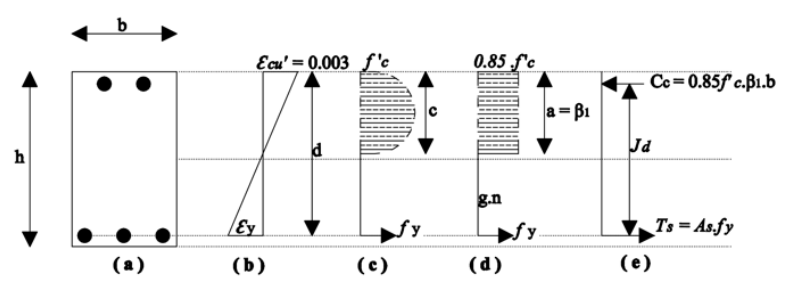

Fig. 1. Concrete stress-strain distribution
a) Beam cross section
b) Actual stress diagram
c) Strain diagram
d) Square stress diagram

e) Equivalent rectangular stress block 
Whereas :

$b=$ beam width $(\mathrm{mm})$

$h=$ beam height $(\mathrm{mm})$

$a=$ square stress distribution height ( $\mathrm{mm}$ )

$c=$ neutral line distance from outermost compressive fibre

$d=$ effective depth of cross section ( $\mathrm{mm})$

$C c=$ concrete compressive force $(\mathrm{N})$

$T s=$ reinforcement tensile strength $(\mathrm{N})$

$J d=$ Cc distance to $\mathrm{Ts}(J d=\mathrm{d}-\mathrm{a} / 2)(\mathrm{mm})$

$f^{\prime} c=$ concrete compressive strength $(\mathrm{MPa})$

$A s=$ reinforcement cross-sectional area $\left(\mathrm{mm}^{2}\right)$

Based on Figure.1, then :

$$
\begin{gathered}
C c=0,85 f^{\prime} c \cdot a \cdot b \\
T s=A s \cdot f y \\
\sum F_{x}=0 \quad \text { then } T s=C c \\
\text { As. } F y=0,85 f^{\prime} c \cdot a \cdot B \\
a=\frac{A s \cdot f y}{0,85 f^{\prime} c \cdot b}
\end{gathered}
$$

Based on the forces that work above, the nominal moment of the cross section is:

$$
\sum M=0 \quad \text { then } T s \cdot j d=M n
$$

Because Ts $=\mathrm{Cc}$ then Mn can be:

$$
\begin{gathered}
M n=A s \cdot f y \cdot j d \\
M n=0,85 f_{c}^{\prime} \cdot a \cdot b \cdot\left(d-\frac{a}{2}\right) \\
M_{\mathrm{n}}=A_{s} \cdot f_{y} \cdot\left[\mathrm{d}-\frac{A_{s} \cdot f_{y}}{1,7 \cdot f_{c}^{\prime} \cdot b}\right]
\end{gathered}
$$

If the concrete beam that installed with FRP then the flexure strength that occur as in the Figure 2, whereas $T f$ is FRP tensile strength and $j d f$ is the distance from $C c$ to Tf.

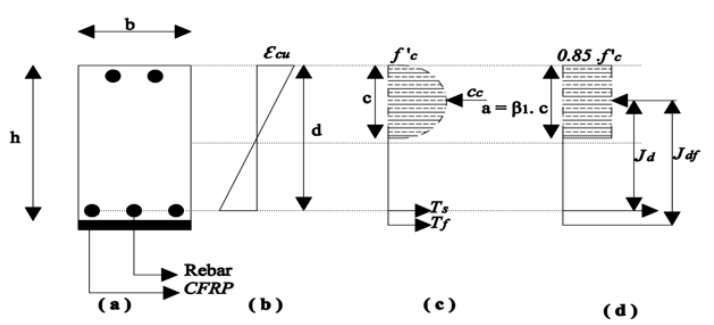

Fig. 2. Concrete stress-strain distribution

a) Beam cross section c) Actual stress diagram

b) Strain diagram d) Square stress diagram Whereas:

e) Equivalent rectangular stress block

Tf $\quad=$ FRP tensile strength $(\mathrm{N})$

$J d_{f} \quad=C c$ distance to $T f(\mathrm{~mm})$

$f y_{f} \quad=$ FRP tension $(\mathrm{Mpa})$

$A s_{f} \quad=$ FRP cross-section $\left(\mathrm{mm}^{2}\right)$

Based on Figure 2, then :

$$
\begin{gathered}
T f=A s_{f} . f y_{f} \\
C c=T s+T f \\
0,85 f^{\prime} c \cdot a \cdot b=A s . f y+A s f . f y f \\
a=\frac{A s \cdot f y+A s f \cdot f y f}{0,85 f^{\prime} c \cdot b} \\
M n=A s . f y \cdot j d+A s f \cdot f y f \cdot j d f
\end{gathered}
$$

$$
M_{n}{ }^{\prime}=(1-\delta) \cdot A_{s} \cdot f_{y} \cdot\left[\mathrm{d} \cdot \frac{(1-\delta) A_{s} \cdot f_{y}}{1,7 \cdot f_{c}^{\prime} \cdot b}\right]+\delta \cdot A_{s} \cdot f_{y} \cdot\left(\mathrm{d}^{-\mathrm{d}^{\prime}}\right)+\varphi \cdot A_{s f} \cdot f_{y f} \cdot j_{d f}
$$

Equation (5) is used for a reinforced concrete beam with single reinforcement while equation (13) is used for a reinforced concrete beam with double reinforcement. Based on both equation (9) and (14), there is an addition to the flexural capacity in the amount of (Asf, fyf, jdf). Therefore, it can be concluded that by adding FRP, the flexural capacity will increase.

\section{Research Method}

The method of this research was an experimental study conducted at the Structure Laboratory USU. The flowchart of the experiment shows in Figure 3.

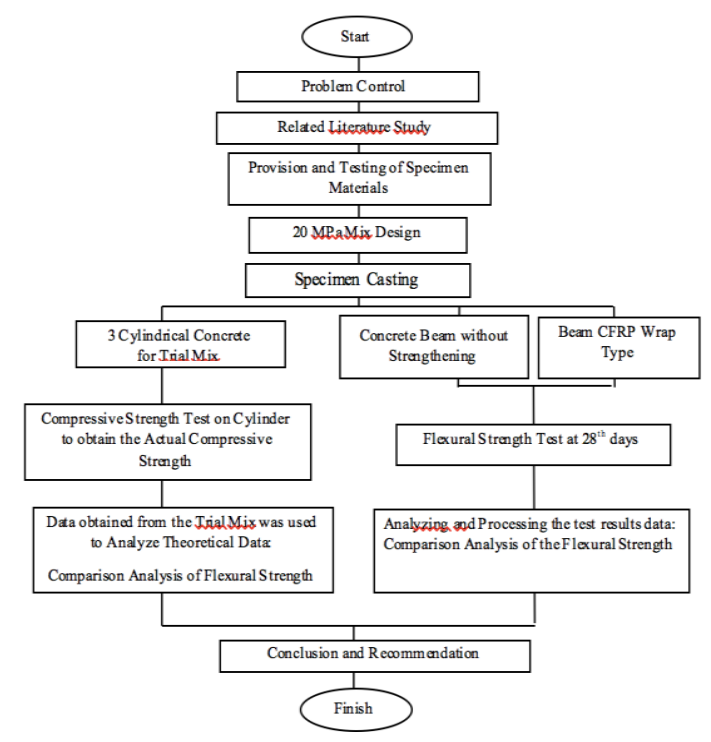

Fig. 3. Flowchart of the experiment

Specimens used in the research consisted of two beam specimens had a dimension of width of $15 \mathrm{~cm}$ and high of $25 \mathrm{~cm}$, span length of $320 \mathrm{~cm}$, for the flexural test with a planned concrete quality of $f^{\prime} c 20 \mathrm{MPa}$, see Figure 5 in which one reinforced concrete beam did not use strengthening $(\mathrm{BK})$, and one reinforced concrete beam used CFRP Wrap type $(\mathrm{BCw})$ reinforcement. The beams were placed above a static loading frame with joints- 
rollers plotting, and the distance between the plots was $3000 \mathrm{~mm}$. The load was conducted by a centralized load system with a distance between the load was $1000 \mathrm{~mm}$ to obtain a pure flexure.

There were 3 dial gauges installed on the low part of the beams to read its deflection on $1 / 4 \mathrm{~L}$ point from the left, middle, and $1 / 4 \mathrm{~L}$ from the right. Data of the load addition and deflection were recorded and were inserted into a table. The load was stopped after there was a crack and when the dial gauge reading did not increase. The flexural strength test of the concrete beam was conducted based on ASTM C-78

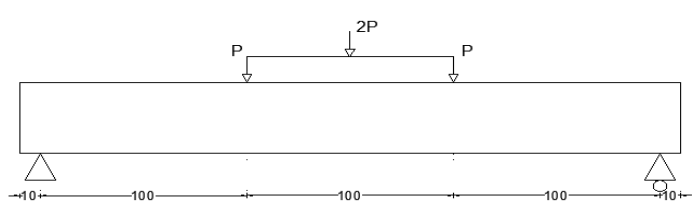

Fig. 4. Beam testing Model Spann $\mathrm{L}=210 \mathrm{~cm}$

In previous studies conducted by Manna Haloho and Johannes Tarigan ${ }^{4}$ where the maximum load was 29,460 N. With the above equation (4) and (5) the number of reinforcement is calculated 4 diameter $12 \mathrm{~mm}$ at the bottom and 2 diameter 8 at the top and stirrup diameter 6 $-15 \mathrm{~cm}$, see figure $6 \mathrm{a}$. For the reinforcement $\varnothing 12$ gained the yield stress of $289 \mathrm{MPa}$ and ultimate stress of 428 MPa.

After that with the same beam size, the addition of a CFRP Wrap under a concrete beam with a size as shown in Figure $6 b$ with a thickness of $0.133 \mathrm{~mm}$, see figure $6 b$. From equation (14) the capacity of moment will be increase. Thus the load to be carried by the beam will be larger and also the deflection becomes larger. In this experiment load and deflection are measured manually. CFRP is installed the bottom beam until the neutral line along the beam.

How to install CFRP are as follows: Clean the surface of the beam that will be installed CFRP. Then apply the adhesive to the surface of the beam that has been cleaned. After that install CFRP above of adhesive. The material of adhesive is epoxy.

CFRP used in this research was Sika Wrap $231 \mathrm{C}$ that had a higher carbon content and the kind that was frequently used. a)

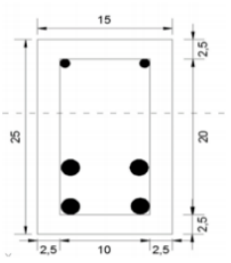

b)

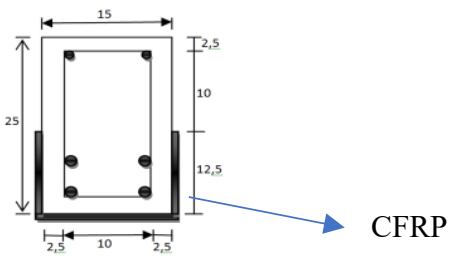

Fig. 5. a) Beam without GFRP

b) Beam with GFRP Wrap type

In Figure 6 can be seen the experimental preparation

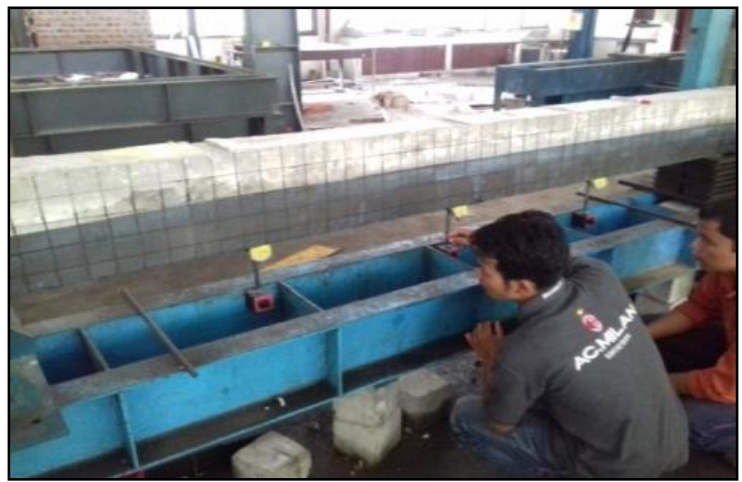

Fig 6. The Process of the Beam Flexure Strength Test

The beam that has been installed CFRP Wrap. Under the beam 3 deflection measuring devices gauges have been installed.

\section{Research Results}

After the analysis has been conducted on reinforced concrete beam based on ACI Committee $440^{8}$ then the analysis result of the beam theoretically as can be seen on Table 2. The Calculation of load at beam can be use equation (2) and (6). 
Table 2. Deflection of Reinforced Concrete Beam ${ }^{9}$

\begin{tabular}{|l|c|c|}
\hline \multicolumn{1}{|c|}{ Samples } & $\begin{array}{c}\text { Ultimate } \\
\text { Load (N) }\end{array}$ & $\begin{array}{c}\text { Maximum } \\
\text { Deflection (mm) }\end{array}$ \\
\hline $\begin{array}{l}\text { Beam without } \\
\text { Strengthening (BK) }\end{array}$ & 29,460 & 17 \\
\hline $\begin{array}{l}\text { Beam with Steel Plate } \\
(\mathrm{BB})^{4}\end{array}$ & 77,050 & 14 \\
\hline $\begin{array}{l}\text { Beam with CFRP } \\
\text { Plate (BCp) }\end{array}$ & 87,310 & 22 \\
\hline $\begin{array}{l}\text { Beam with GFRP } \\
\text { Wrap (BGw) }\end{array}$ & 84,780 & 29 \\
\hline $\begin{array}{l}\text { Beam with CFRP } \\
\text { Wrap (BCw) }\end{array}$ & 94,700 & 31 \\
\hline
\end{tabular}

As seen in Table 2 thus theoretically beam with CFRP Wrap can hold the biggest deflection and a maximum load better than the others. According to the graph above based on theoretical analysis, the ultimate load amount of beam without strengthening was $29,460 \mathrm{~N}$, beam with steel plate was $77,050 \mathrm{~N}$, beam with CFRP plate was $87,310 \mathrm{~N}$, beam with GFRP wrap was 84,780 $\mathrm{N}$ and beam with CFRP wrap was $94,700 \mathrm{~N}$. Based on table 2 the increased load on the steel plate was 2.61 times, on CFRP was 2.96 times, on GFRP wrap was 2.67 times and on CFRP wrap was 3.12 times.

After the reinforced concrete beam examination has been conducted based on $A S T M C 78 / C 78 M^{8}$ the beam test result can be seen on Table 3 .

Table 3. Deflection of Reinforced Concrete Beam

\begin{tabular}{|l|c|c|}
\hline \multicolumn{1}{|c|}{ Samples } & $\begin{array}{c}\text { Ultimate } \\
\text { Load (N) }\end{array}$ & $\begin{array}{c}\text { Maximum } \\
\text { Deflection } \\
\text { (mm) }\end{array}$ \\
\hline $\begin{array}{l}\text { Beam without } \\
\text { Strengthening (BK) }\end{array}$ & 90,000 & 22.45 \\
\hline $\begin{array}{l}\text { Beam with Steel } \\
\text { Plate (BB) }\end{array}$ & 195,000 & 26.80 \\
\hline $\begin{array}{l}\text { Beam with CFRP } \\
\text { Plate (BCp) }\end{array}$ & 220,000 & 28.98 \\
\hline $\begin{array}{l}\text { Beam with GFRP } \\
\text { Wrap (BGw) }\end{array}$ & 210,000 & 29.69 \\
\hline $\begin{array}{l}\text { Beam with CFRP } \\
\text { Wrap (BCw) }\end{array}$ & 225,000 & 30.21 \\
\hline
\end{tabular}

From the Table 3 we can see that, on beam without strengthening (BK) the amount of ultimate load is 90,000 $\mathrm{N}$, on beam with steel plate $(\mathrm{BB})$ the amount of ultimate load is $195,000 \mathrm{~N}$, on beam with CFRP Plate (BCp) the amount of ultimate load is $220,000 \mathrm{~N}$, on beam with GFRP Wrap (BGw) the amount is $210,000 \mathrm{~N}$ and on beam with CFRP Wrap (BCw) in the amount of 225,000 kg. Base on Table 3 the increased load on steel plate was 2.16 times, while on CFRP Plate 2.44 times and GFRP Wrap as big as 2.33 times also CFRP Wrap as big as 2.51 times.

\section{Conclusion}

The results from this test can be concluded as:

Based on theoretic analysis as well a test result it is proven that by adding external strengthening whether CFRP Plate and Wrap, GFRP Wrap and Steel Plate can increase beam ability on carrying flexure much more better than its normal condition (without strengthening).

After being calculated analytically the result are as follows: beam without strengthening has ultimate load in the amount of $29,460 \mathrm{~N}$, beam with Steel Plate in the amount of $77,050 \mathrm{~N}$, beam with CFRP Plate in the amount of 87,310 N, beam with GFRP Wrap 84,780 N and beam with CFRP Wrap in the amount of 94,700 N. From this analysis obtained on Steel Plate there is an increase in load of 2.61 times, while on CFRP Plate is 2.96 times; on GFRP Wrap is 2.67 times, and on CFRP Wrap is 3.12 times.

According to experimental result, on beam without strengthening has ultimate load in amount of $90,000 \mathrm{~N}$, on beam with Steel Plate in amount of 195,000 N, on beam with CFRP Plate in amount of 220,000 N, on beam with GFRP Wrap in the amount of $210,000 \mathrm{~N}$, and on beam with CFRP Wrap in the amount of 225,000 N. From this experimental result, there is an increase in load of Steel Plate of 2.16 times, while on CFRP Plate is 2.44 times; GFRP Wrap is 2.33 times and CFRP Wrap is 2.51 times.

Among the four types of strengthening that has been tested, it can be concluded that strengthening with CFRP Wrap as the best solution to increase concrete beam ability on carrying flexure, followed by CFRP Plate, GFRP Wrap and Steel Plate.

\section{References}

1. E. Pangestuti, Nuroji dan Antonius. Penggunaan Carbon Fibre Reinforced Plate Sebagai Tulangan Eksternal Pada Struktur Balok Beton Bertulang PILAR 15, 86-94 (2009) [in Indonesian].

2. I. Petrico. Perbandingan Kekuatan Lentur Balok Beton Bertulang dengan Menggunakan Perkuatan CFRP Dan GFRP 1, 250-258 (2013) [in Indonesian].

3. A. Alnadher, A. Jamal, H. Rami, dan G. Khaled. CFRP Mechanical Anchorage for Externally Strengthened RC Beams under Flexure Physics Procedia 55, 10-16 (2014)

4. Manna Haloho dan Johannes Tarigan. Perbandingan Kekuatan Balok Beton tanpa Perkuatan dengan Balok Beton Menggunakan Pelat Baja yang Diangkur 1, 8 (2015) [in Indonesian].

5. Ivandi Yoman dan Johannes Tarigan. Perbandingan Kekuatan Balok dengan Pelat Baja dan Fiber Reinforced Polymer, 15 (Medan: Universitas Sumatera Utara,2016) [in Indonesian].

6. J. Tarigan, M. Patra, T. Sitorus. Flexural strength using Steel Plate, Carbon Fiber Reinforced Polymer (CFRP) and Glass Fiber Reinforced Polimer $(G F R P)$ on reinforced concrete beam in building technology, (IOP Conference Series: Earth and Environmental Science 126(1) 012025 (2018) 
7. ASTM C78/C78M - 16 Standard Test Method for Flexural Strength of Concrete Using Simple Beam with Third-Point Loading 4, 45-87 (2016)

8. ACI 440 Committee, Guide for the Design and Construction of Externally Bonded FRP Systems for Strengthening Concrete Structures 3, 43-80 (2008)

9. A. A. Pakpahan dan Johannes Tarigan. Analisa dan Eksperimental Penggunaan CFRP Tipe Wrap Pada Perkuatan Lentur Balok Beton 1, 12 (2017) [in Indonesian]. 